\title{
THE EUROPEANIZATION OF CENTRAL AND EASTERN EUROPE
}

\author{
Mădălina-Ștefania Dîrzu ${ }^{1}$ \\ "Alexandru Ioan Cuza" University of Iaşi \\ dirzu_madalina@yahoo.com
}

\begin{abstract}
The Central and Eastern Europe Countries (CEECs) have been shaped by the EU conditionality, meaning that these countries were obliged to develop their administrative capacities in completely convergence with the acquis communautaire in order to join the European Union. The 2004 and 2007 enlargement of the EU and the accession negotiations have brought a systemic transformation of the CEECs through what is known in the literature as Europeanization. It seems to be a strong connection between conditionality and Europeanization, the former giving way to the latter. Therefore the capacity and the willingness of candidate countries to transfer the acquis into the domestic legal context have had a significant influence in the way in which the Europeanization process has succeeded in inhabiting the governance system of the CEECs.

Considering these, the purpose of this paper is to examine through which mechanisms it was realized the correspondence between EU conditionality and the process of central and eastern enlargement-led Europeanization which seems to have been internalized distinctively by the CEECs, where administrative resources to comply with European standards were lagging behind.
\end{abstract}

Keywords: Europeanization, conditionality, European Union, CEECs

JEL Classification: R11, R38

\section{INTRODUCTION}

In the case of the CEECs, the Europeanization process involved transformation as a response to European Union pressures (conditionality), in order to be part of the EU. This "Twinning exercise" (Papadimitriou and Phinnemore, 2004) has represented an instrument for the CEECs governments to transfer the acquis communautaire into their institutions and practically to empower Europeanization to be part of the domestic system. As we shall see, the CEECs have linked their economic, social and political development with the European Union and regarded their Europeanization as a desirable and modernizing change (Anastasakis, 2005). But it remains one

\footnotetext{
${ }^{1}$ Acknowledgements: This work was supported by the European Social Fund in Romania, under the responsibility of the Managing Authority for the Sectorial Operational Programme for Human Resources Development 2007-2013 [grant POSDRU/CCP 107 DMI 1.5/S/78342]
} 
vital question 'what does Europeanization truly mean?'. This issue of Europeanization is increasingly analyzed in the recent European studies and also more and more debates are developed around this intriguing theme.

To begin with, we have to admit that Europeanization has become an influential and fashionable locution in social scientific terminology, likewise in the commonplace discourses on Europe. Commencing from the multiplicity of use, this term can have a concrete and specific meaning and, at the same time, evasive and all-embracing. Europeanization signifies a means and an end; it represents method as well as substance; it defines a project and a vision (Anastasakis, 2005). Moreover, this concept evidences a specific political, socioeconomic and cultural reality, but concurrently it symbolizes an ideology and a myth. More than that, it has universal value by cause of its historical, aggregate and global nature. Also, its influence determines internal repercussions for Europe and, at the same time, an external implication for the rest of the world. Europeanization involves diverse meanings in various states or regions included in this process: for the emergent eastern European countries, it signifies structural reformation and modernization; for the developed countries of Central Europe, it means a light exercise of reliable reform and adaptation.

\section{LITERATURE REVIEW}

The study of Europeanization has acquired momentum in international relations literature. It has become stimulating for the analysts because it represents a model-building mechanism - a political system in the making which generates verdicts and influences the domestic structures (Bulmer and Radaelli, 2004). A lot of definitions about Europeanization pinpoint the European Union at the center of the debate, taking into consideration the fact that EU has attributed to this concept a more systematic, concrete and structured meaning - so much so that nowadays Europeanization is perceived factually as "EU-ization" (Anastasakis, 2005). Taking into account this last aspect, Radaelli defines Europeanization as "processes of (a) construction, (b) diffusion and (c) institutionalization of formal and informal rules, procedures, policy paradigms, styles, "ways of doing things", and shared beliefs and norms which are first defined and consolidated in the EU policy process and then incorporated in the logic of domestic discourse, identities, political structures and public policies" (Radaelli, 2000). This interpretation is extremely comprehensible because it reveals Europeanization as a bilateral process, not just a simple unidirectional process to Europe (Salgado and Wall, 2004).

To be absolutely fair, we have to recognize that world-class European analysts proved to be unable in coming up with a single definition for this complex concept called "Europeanization". By 
reviewing a certain number of contributions to the study of Europeanization, a broad description of the concept will be provided in order to set the context. Firstly, it should be said that this term has many possible meanings and it is used in several ways to describe a variety of phenomena and processes of transformation. For a profound understanding, we should look for an ample definition, following Johan Olsen's approach, according to which there are five different, but related phenomena called Europeanization, with the essential mention that all these diverse conceptions complement, rather than exclude each other. Hence the author identifies five possible meanings of the term "Europeanization": transformation in external territorial boundaries (enlargement), developing institutions of governance at the European level, central penetration of domestic systems of governance, exporting forms of political organization, a political unification project (Olsen, 2002).

Beyond the variety of significations identified by Olsen, in the literature dedicated to Europeanization, we can remark a "mainstream meaning" of Europeanization, which represent a composite concept. Considering this, Europeanization appears to be a complex term that covers a set of phenomena describing a different process, being defined by the next four dimensions (Strang, 2007):

- adjustment of local policies to EU exigencies and policies (downloading);

- domestic projection of Member States' interests, or the effort of Member States to promote their interests into the agenda and policies of the EU (uploading);

- elite socialization;

- bureaucratic re-organization.

As we can observe, Europeanization represents a complex process of transformation for the candidate countries, in order to be part of the European Union.

\section{THE IMPLENTATION OF THE EUROPEANIZATION PROCESS IN THE CEECS}

During the accession negotiations to EU, the Central and Eastern European Countries had to shape their administrative systems and to develop an uniform model of public administration in order to join the European Union. All this process called Europeanization was possible by using five conditionality instruments (Grabbe, 2001). The first instrument is gate keeping which means the access to negotiations and other steps in the accession process to European Union. In the second place, benchmarking and monitoring, an instrument utilized for supervising the progress of the applicant states. In the third place, provision of legislative and institutional transformations, which refers to the legal transfer of the acquis communaitaire and the harmonization with EU regulations. 
In the forth place, money, which relates to the aid and technical assistance in order to develop the institutional capacity of the candidate countries. And finally, in the fifth place, advice and twinning, which involves support from the EU officials for the administrative institutions of the CEECs to comply with the acquis.

All these five mechanisms presented above are shaping policy-making in CEECs, but most importantly is the fact that European Union has made use of the asymmetry of power to fulfill a vital goal: the Europeanization of the policies of the candidate countries. More than that, this asymmetry of power is enforced by conditionality and evidences the top-down relationship between the EU and the applicant states (Ladrech, 1994).

After the collapse of communism, Europeanization took the following turn: this "EU-ization" process was associated with enlargement of the EU to the East. The objective of Europeanization covered the impact of EU integration on eastern countries with previously different economic and political experience. Europeanization of the CEECs, process called "The Eastern style" (Goetz, 2001) refers to the transgression to democracy and a market economy and adaptation to the standards of the developed models of the West (Anastasakis, 2005). In this sense, Europeanization in the preparatory stage of pre-accession has represented an externally driven process of reformation defined by the EU centers of power.

As it was mentioned above, EU has presented a variety of requirements that candidate countries had to fulfill in order to receive the most important reward from EU, meaning the full membership. In order to achieve such an output, EU political conditionality has also followed the strategy of reinforcement by reward (Schimmelfenning and Sedelmeier, 2004). For a profounder analyze of EU political conditionality in the enlargement process, in the following it will be described three crucial criteria: the size of the reward extending the costs of compliance, credibility and determinacy of conditions.

Commencing with the size of the reward, indubitably the promise of full membership had a fundamental impact on the candidate states than any other incentive advanced by EU. The inducements which were directed to CEECs referred to the access to internal market, access to the subsidies of the European Union's regional and agricultural policies, complete collaboration in the decision making process, barely to name the most fundamental ones. These inducements have helped to readjust the costs and benefits of the exigencies' fulfillment and in this way they have fortified a profounder compliance of the targeted governments (Schimmelfenning and Sedelmeier, 2004).

The credibility of European Union's conditionality which refers to EU's menace to keep back the reward of full membership in case of failing to adopt the rules, on the one hand, and on the other 
hand, to the promise to offer the reward in case of compliance, were both at a very high level. In what concerns the determinacy of the conditions, here there are some shortcomings.

In what concerns the determinacy of the conditions, here there are some shortcomings. The political conditions have been ambiguously defined and therefore caused disorientation within targeted governments regarding the necessary steps to take that would have satisfied Brussels (Mineshima, 2002).

\section{CONCLUSIONS}

Taking into consideration all the aspects of EU's conditionality which have been presented above, it must be mentioned that in the absence of central and eastern enlargement and accession conditionality - the so called Europeanization process, the export of EU rules would have remained limited and patchy and the CEECs would have remained some "weak states" incapable to develop in harmonization with European standards and to become part of the EU.

Needless to say, the internalization of Europeanization proved to be heterogeneous from country to country. This aspect can be easily observed in different levels of political and socioeconomic performance. For instance, in the eastern countries such as Romania and Bulgaria, here still are a variety of problems: political elites are corrupt and ineffective, human capital is limited with a strong predilection to migrate in more developed states, public administrations prove to be perpetually anemic etc. This non-uniform internalization of Europeanization demonstrates that, although, this process in different countries may be based on identical exogenous principles and the operation of similar instruments, eventually Europeanization proves to be a distinctly national exercise of reformation and adjustability. It represents a path of domestic transformation in witch every country adapts its policies, processes and institutions to new rules, procedures and practices emanating from the same European system of governance.

Finally, it must be added that in the short and medium term, this Europeanization process may be linked with oblations and complicated socio-economic and political choices for the countries involved. On the other hand, in the long term, Europeanization is synonymous with development, modernization, stability and a certain security based on light power and the advantages of cooperation and co-existence. In other words, with this accession to the EU, new members have become more engaged in internal EU processes. Consequently, the Central and Eastern Europeancountries are now better place to influence the agenda and the direction of Europeanization . 


\section{REFERENCES}

Anastasakis, O. (2005) The Europeanization of the Balkans, The Brown Journal of World Affairs, vol. XII, no. 1.

Bulmer, S., Radaelli, C. (2004) The Europeanization of National Policy, Queen's Papers on Europeanisation, no. 4.

Goetz, K. (2001) Making sense of post-communist central administration or latinization, Journal of European Public Policy, vol. 8, no. 6.

Grabbe, H. (2001) How Does Europeanisation Affect CEE Governance? Conditionality, Diffusion and Diversity, Journal of European Public Policy, vol. 8, no. 6.

Ladrech, R. (1994) Europeanization on Domestic Politics and Institutions: The Case of France, Journal of Common Market Studies, vol. 32, no. 1.

Mineshima, D. (2002) The Rule of Law and EU Expansion, Liverpool Law Review, vol. 24.

Olsen, J. P. (2002) Many Faces of Europeanization, Journal of Common Market Studies, vol. 40, no. 2 .

Radaelli, C. (2000) Wither europeanisation? Concept stretching and substantive chance, European Integration Online Papers 3, no. 7, accessed online on February 5, 2011 at http://eiop.ot.at/eiop/comment/1999-007c.htm.

Papadimitriou, D. and Phinnemore, D. (2004) Europeanization Conditionality and Domestic Change: the Twinning exercise and administrative reform in Romania, Journal of Common Market Studies, vol. 42, no. 3.

Salgado, S. R., Woll, C. (2004) L'Europeanisation et les acteurs non Etatiques, Paper delivered to the conference on Europeanisation of Public Policies and European Integration, IEPParis, accessed online on February 2, 2011 at http://www.sciencespo.fr/recherche/forum_european/prepublications/Papier_2_Woll_Salga do.pdf.

Schimmelfenning, F., Sedelmeier, U. (2004) Governance by Conditionality: EU Rule Transfer to the Candidate Countries of Central and Eastern Europe, Journal of European Public Policy, vol. 11, no. 4;

Strang, B. (2007) Winds of Change: the Europeanization of National Foreign Policy, Maastrich European Studies Papers. 